\title{
C-REACTIVE PROTEIN (CRP) AS A SUPPORTING MARKER OF ANTIBIOTIC EFFECTIVENESS ON CENTRAL NERVOUS SYSTEM (CNS) INFECTIONS
}

\author{
Melawati $\mathrm{O}^{1}$, Yulistiani ${ }^{2}$, Darto Saharso ${ }^{3}$, Nun Zairina ${ }^{4}$ \\ ${ }^{1}$ Post graduate Student of Master of Clinical Pharmacy Program, Faculty of Pharmacy, Airlangga University, \\ ${ }^{2}$ Pharmacy Department, Dr Soetomo Teaching Hospital, ${ }^{3}$ Neurology Division, Pediatric Department, Dr Soetomo \\ Hospital, ${ }^{4}$ Clinical Pharmacy Department, Faculty of Pharmacy, Airlangga University
}

\begin{abstract}
ABSTRAK
Infeksi susunan saraf pusat pada pasien anak memiliki mortalitas yang tinggi dan mempunyai gejala sisa neurologis. Tanda-tanda pada penyakit ini hampir tidak terlihat. Pemeriksaan yang ideal untuk penyakit tersebut adalah melalui cairan serebrosipinal (CSS). Namun dalam pemeriksaan banyak kendala yang dihadapi. Inisiasi pemberian terapi antibiotika yang tepat menjadi kunci utama dalam menurunkan morbiditas dan mortalitas. Pemberian terapi empirik sebaiknya didasarkan pada pola sensitivitas kuman yang terbaru. Hasil kultur mikrobiologis baru didapatkan dalam waktu 5-7 hari. Selama menunggu hasil efektifitas penggunaan antibiotika empirik masih dipertanyakan. Oleh karena itu dilakukan pemeriksaan penunjang lainnya dalam menentukan efektifitas antibiotika dengan menggunakan salah satu marker yaitu CRP. Tujuan dari penelitian ini untuk membuktikan kadar CRP darah sebagai marker penunjang efektivitas terapi antibiotika pada pasien anak dengan infeksi sususnan saraf pusat (SSP). Sebuah studi kohort prospektif dilakukan untuk mengetahui hubungan CRP dengan paremeter perbaikan klinis, laboratoris dan mikrobiologi pasien anak dengan infeksi susunan saraf pusat. Pasien yang memenuhi kriteria diambil sampel darah sebelum (HO), hari ketiga (H3) dan hari kelima (H5) pemberian antibiotika untuk diperiksa CRP. Penelitian ini terdiri dari 10 pasien dengan infeksi susunan saraf pusat (meningitis, meningoensefalitis, ensefalitis dan edema serebral). Enam pasien adalah laki-laki, dengan usia $<1$ tahun. Pada efektifitas pemberian antibiotika yang dikaitkan dengan perbaikan kondisi pasien dengan nilai CRP sebelum (HO) 3.558 \pm 3.196 , hari ketiga (H3) 3.878 \pm 2.813 dan hari kelima (H5) 3.891 \pm 2.204 sesudah pemberian antibiotika dan pada konsentrasi WBC

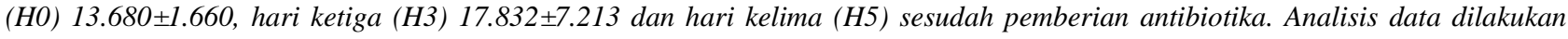
dengan menggunakan uji korelasi Pearson pada parameter CRP-WBC HO p=0.981, CRP-WBC H3 $p=0.621$ dan CRP - WBC H5p=. 0.644. Tidak terlihat korelasi yang signifikan antara CRP dan WBC sebelum dan sesudah pemberian antibiotika. Simpulan, tidak ada korelasi kadar CRP dengan parameter klinik, laboratoris dan mikrobiologis pada pasien dengan infeksi susunan saraf pada kondisi critical ill.(FMI 2015;51:149-155)
\end{abstract}

Kata kunci: CRP, infeksi pada susunan saraf pusat, leukosit, marker penunjang, efektifitas antibiotika

\begin{abstract}
Infection of the central nervous system in pediatric patients have a high mortality as well as acute and chronic neurological sequelae. Signs of the disease are unclear, so cerebrospinal fluid (CSF) test is used as a gold standard for diagnosis, but the investigation has faced many obtacles. Empiric antibiotic therapy is the key factor in reducing morbidity and mortality. Microbiological culture result is obtained within 5-7 days. The effectiveness of empirical antibiotic use is questionable. Therefore, other investigations are conducted to determine the effectiveness of antibiotics by using one marker, the CRP. This study was to analyze CRP level in supporting antibiotic therapy effectiveness in pediatric patients with central nervous system (CNS) infections. A prospective cohort study was conducted to determine the relationship of CRP with other parameters, including clinical, microbiological and laboratory, in pediatric patients with central nervous system infections. Patients meeting blood samples criteria were taken before (HO), the third day (H3) and the fifth day (H5) after antibiotics administration. This study involved 10 patients with central nervous system infections (meningoencephalitis, encephalitis and encephalitis with cerebral edema). Six patients were male, with ages less than a year. Antibiotic treatment effectiveness was associated with improved condition of the patients' CRP level. It was $3.558 \pm 3.196$ before (HO), $3.878 \pm 2.813$ on the third day (H3) and $3.891 \pm 2.204$ on the fifth day (H5) after antibiotic administration. Leukocyte levels were $13.680 \pm 1.660$ before (HO), 17.832 \pm 7.213 on the third day (H5), and $10.546 \pm 3.671$ on the fifth day (H5) after antibiotic administration. Pearson's correlation test analysis performed on CRP and WBC parameters showed HO $p=0.981$, CRP and WBC H3 $p=0.621$, while CRP and WBC H5 obtained significance $p=0.644$. There was no significant correlation observed between CRP and WBC parameters before and after antibiotic administration. In conclusion, there was no correlation of CRP levels with clinical, laboratory and micobiological parameters in patients with central nervous system infections.(FMI 2015;51:149-155)
\end{abstract}

Keywords: CRP, infection of the central nervous system, leukocyte, as supporting marker, antibiotic effectiveness.

Correspondence: Melawati Olevianingrum, Jl. Pondok Maritim Indah blok AA/26 Surabaya, +6285655839928, melasubroto@gmail.com 


\section{INTRODUCTION}

Infection of the central nervous system (CNS) describes a variety of infections involving brain and spinal cord and associated tissues, including meningitis (bacterial meningitis, TB meningitis and meningoencephalitis), encephalitis, brain abscess and ventriculitis (Dipiro 2011). Infection of the Central Nervous System (CNS) poses a serious medical problem with a high mortality rate and requires immediate treatment to minimize serious neurological sequelae and ensure the survival of patients (Ziai et al 2008, Barrichello et al 2013). Microorganism replication in the CNS is associated with the release of compounds, such as peptidoglycan, a cell wall fragment, lipoteichoic acid and lipopolysaccharide, which can cause an increase in body inflammatory response (Barrichello et al 2013). CNS infection has neurological sequelae of acute and chronic conditions, including seizures, hydrocephalus, focal neurological deficits, cognitive deficits and personality changes (Ziai et al 2008).

In Indonesia, cases of bacterial meningitis are found in about 158 cases per year with etiology caused by Haemophilus influenzae B (Hib) bacteria and other bacteria in 67 cases. It is a high figure when compared with those in developed countries (Anggraini 2011). The mortality rate of bacterial meningitis in the USA was in about $10 \%$ of patients, whereas approximately $40 \%$ of patients experienced bacterial meningitis sequelae, including hearing loss, hydrocephalus and others (Chavez-Bueno 2005). Delayed diagnosis establishment and less effective early treatment, and the use of secondline antibiotics are shown to increase the risk of sequelae and complications up to 50-65\% (Urowayin et al, 2004; Novariani 2008; Anggraini 2011). Signs of meningitis are hardly seen in children (Garges 2006). Examination ideal for meningitis is the examination of the cerebrospinal fluid (CSS). However, culture examination CSS still faces obstacles, ie. the problems of CSS sampling, culture results only provide information on $60-80 \%$ bacterial infections, and sometimes showed a negative or with sterile culture results, so that definitive antibiotic selection based on culture results cannot be provided (Alain et al, 2011).

Early diagnosis and initiation of appropriate antibiotic therapy is still the key factor in reducing morbidity and mortality in CNS infections. The use of the antimicrobial therapy must be initiated before culture results are obtained. Selection of antibiotics for empiric therapy is done based on the latest pattern of germ sensitivity. The waiting time for CSS culture results requires a minimum of 2-3 days (Taskin et al, 2004; Ziai and Lewin, 2008). In Dr. Soetomo Hospital, new microbiological culture results are obtained within 5-7 days. While waiting for the result, the effectiveness of empirical antibiotic therapy is still questionable (Ehl et al 1997). In addition to the WBC, examination using CRP has been widely used in support of infectious conditions, particularly bacterial infection (Chan et al 2002). Therefore, efforts to other examinations were conducted to determine the effectiveness and success in the use of antibiotics during the clinical course of treatment, such as by using one of the markers, the C-reactive protein (CRP).

Measurement of acute phase proteins like C-reactive protein (CRP) provides an alternative method for assessing the presence of infection and as a marker of acute inflammation. CRP is a cell globulin synthesized by hepatocytes and secreted into the blood. CRP levels will increase in the event of a local or systemic inflammatory response and more specifically on infectious diseases that occur in neonates such as neonatal sepsis and bacterial meningitis. Although CRP is a nonspecific marker, CRP has several times proven that in condition of sepsis and bacterial meningitis there is also an increase in CRP concentration. In bacterial meningitis caused by $N$. meningitidis, blod CRP concentration is less than $1 \mathrm{mg} / \mathrm{dl}$ and may reach 10 $\mathrm{mg} / \mathrm{dl}$ for 24-72 hours. The first peak of acute phase response is followed by decay or infection that occurs and decreases rapidly when inflammation stimulus ends. CRP has a half-life in the circulation of about 19 hours. Changes in CRP concentration sufficiently reflect the influence of antibiotic therapy and is useful as a marker to determine the duration of antibiotic therapy (Pourcyros 1993, Clyne, 1999, Pepys et al 2003, Terry 2003, McDade, 2005, Jayanta et al 2013). CRP can also serve as a marker that is very useful in screening for infection and inflammation as well as to monitor the response to treatment of a disease activity (Clyne 1999; Pepys et al 2003).

\section{MATERIALS AND METHODS}

This study was a prospective cohort study conducted at Dr. Soetomo Hospital during the months from July to October 2014. Patients were selected according to inclusion and exclusion criteria. Inclusion criteria were patients of children aged 0-14 years, hospitalized patients with a final diagnosis of central nervous system infections by clinicians, and patients presented willingness to participate in the study and have completed the informed consent. Exclusion criteria were patients with liver disease, diabetes, UTI, burns and with the prefix hydrosefalus. Blood samples were taken before $(\mathrm{H} 0)$, on the third (H3) and the fifth (H5) of antibiotics administration and measured using sandwich ELISA. 
Descriptive analysis showed patients' demographic data. CRP and WBC levels of the patients were taken before (H0), on the third (H3) and fifth (H5) days of antibiotics administration, whereas the blood culture samples were taken before antibiotic administration. The difference between CRP and WBC before and after antibiotic administration was analyzed by Wilcoxon and paired $\mathrm{t}$ test. Correlation between CRP and WBC before and after antibiotic therapy was analyzed using Pearson's correlation test.

\section{RESULTS}

This study was conducted between July to October 2014. There were 16 patients with 3 patients meeting criteria for dropout and 3 meeting the exclusion criteria. In this study, 10 patients met inclusion criteria of age of less than 1 year in 6 patients, and most patients were boys. From 10 patients with blood cultures, the growth of germs was found in only 5 patients. CSS Pathology could only be done in 4 patients because there were contraindications and the families did not allow for CSS sampling. The diagnosis was mostly encephalitis. Profile of patients and the patient's clinical manifestations can be seen in Table 1. Figure 1 shows the levels of CRP and WBC before (H0), on the third (H3) and the fifth (H5) day of antibiotic administration. Table 2 shows WBC profile in 10 patients before $(\mathrm{H} 0)$, on the third (H3) and on the fifth (H5) day of antibiotic administration. Table 3 shows CRP profile in 10 patients before (H0), on the third (H3) and on the fifth (H5) day of antibiotic administration.

Statistical analysis of comparison of WBC between H0$\mathrm{H} 3, \mathrm{H} 5$ and $\mathrm{H} 3-\mathrm{H} 0-\mathrm{H} 5$ antibiotics administration revealed statistical significance of $\mathrm{H} 0-\mathrm{H} 3 \mathrm{p}=0.223$ and $\mathrm{H} 0-\mathrm{H} 5 \mathrm{p}=0.78$. This shows there was no reduction in the levels of WBC before and after antibiotics administration. H3-H5, using t-paired, showed $\mathrm{p}=0.015$, indicating a decline in WBC on the third and fifth day of antibiotics administration. Comparative statistical analysis to all CRP data revealed $\mathrm{p} \geq 0.05$, which indicates no reduction in CRP levels before and after antibiotics administration. In addition, to determine the presence of correlation between CRP and WBC, we performed CRP and WBC correlation analysis before (H0) $(\mathrm{p}=0.981)$, on the third day $(\mathrm{H} 3)(\mathrm{p}=0.621)$ and on the fifth day $(\mathrm{H} 5)(\mathrm{p}=0.624)$ antibiotics administration. Statistical results $\mathrm{p} \geq 0.05$ showed no significant correlation between CRP with WBC before and after antibiotics administration.

Table 1. Characteristics of pediatric patients with central nervous system infections

\begin{tabular}{|c|c|c|c|}
\hline $\begin{array}{c}\text { Patients' } \\
\text { characteristics }\end{array}$ & Notes & $\begin{array}{c}\text { Patient number } \\
(\mathrm{N}=10)\end{array}$ & $\begin{array}{c}\text { Percentage }(\%) \\
(\mathrm{N}=10)\end{array}$ \\
\hline \multirow[t]{2}{*}{ Sex } & Female & 4 & 40 \\
\hline & Male & 6 & 60 \\
\hline \multirow[t]{2}{*}{ Age } & $<1$ year & 6 & 60 \\
\hline & $1-3$ years & 4 & 40 \\
\hline \multirow[t]{3}{*}{ CNS infection } & Encephalitis & 7 & 70 \\
\hline & Encephalitis+Cerebral edema & 2 & 20 \\
\hline & Meningoencephalitis & 1 & 10 \\
\hline \multicolumn{4}{|l|}{$\begin{array}{l}\text { Patient's clinical } \\
\text { signs }\end{array}$} \\
\hline \multirow[t]{2}{*}{ Pulse } & $100-160 x / m i n$ & 10 & 100 \\
\hline & $>160 \mathrm{x} / \mathrm{min}$ & - & - \\
\hline \multirow{2}{*}{ Temperature } & $36,5-37^{0} \mathrm{C}$ & 3 & 30 \\
\hline & $>37^{\circ} \mathrm{C}$ & 7 & 70 \\
\hline \multirow[t]{2}{*}{$\mathrm{RR}$} & 30-60x/min & 9 & 90 \\
\hline & $>60 / \mathrm{min}$ & 1 & 10 \\
\hline \multirow[t]{2}{*}{ Convulsion } & + & 4 & 40 \\
\hline & - & 6 & 60 \\
\hline \multicolumn{4}{|l|}{$\begin{array}{l}\text { Patient's } \\
\text { laboratory }\end{array}$} \\
\hline \multirow[t]{2}{*}{ CRP } & $0-10 \mathrm{mg} / \mathrm{L}$ & 0 & 0 \\
\hline & $>10 \mathrm{mg} / \mathrm{L}$ & 10 & 100 \\
\hline \multirow[t]{4}{*}{ WBC } & $5,0-10,0 \times 10^{3} / \mathrm{mm}^{3}(>2$ years $)$ & 0 & 0 \\
\hline & $>10,0 \times 10^{3} / \mathrm{mm}^{3}$ & 1 & 10 \\
\hline & $6,2-17,0 \times 10^{3} / \mathrm{mm}^{3}(<2$ years $)$ & 6 & 60 \\
\hline & $>17,0 \times 10^{3} / \mathrm{mm}^{3}$ & 3 & 30 \\
\hline Antibiotic types & Ceftriaxone & 10 & 100 \\
\hline \multirow{2}{*}{$\begin{array}{l}\text { Results of blood } \\
\text { culture }\end{array}$} & + & 5 & 50 \\
\hline & Sterile & 5 & 50 \\
\hline
\end{tabular}




\begin{tabular}{llcc}
\hline CNS pathology & & Patients $(\mathrm{n}=4)$ & Percentage (\%) \\
PMN & Positive & 3 & $30^{*}$ \\
Glucose & $>40-80 \mathrm{mg} / \mathrm{l}$ & 1 & $10^{*}$ \\
Protein & $>20-40 \mathrm{mg} / \mathrm{dl}$ & 2 & $20^{*}$ \\
\hline
\end{tabular}

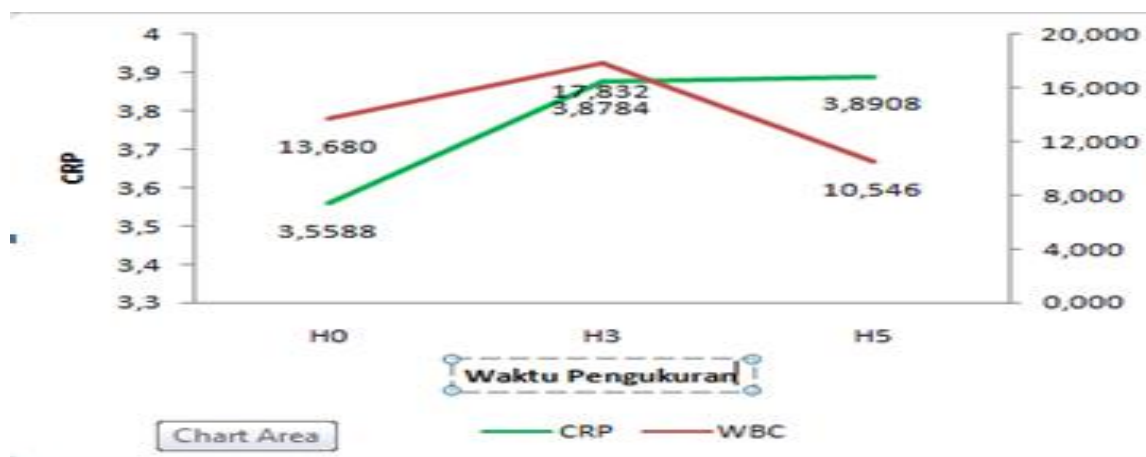

Figure 1. CRP and WBC profile of the patients in $\mathrm{H} 0, \mathrm{H} 3$ and $\mathrm{H} 5$ antibiotics administration in five patients

Table 2. Profile of WBC examination before and after antibiotic therapy

\begin{tabular}{|c|c|c|c|c|}
\hline \multirow{4}{*}{$\begin{array}{c}\text { Patients' } \\
\text { initials }\end{array}$} & \multirow{4}{*}{$\begin{array}{l}\text { Patients' } \\
\text { ages } \\
\text { (months) }\end{array}$} & \multicolumn{3}{|c|}{ WBC values $\left(10^{3} / \mathrm{mm}^{3}\right)$} \\
\hline & & \multirow{3}{*}{$\begin{array}{c}\text { Before antibiotics } \\
\text { Day } 0 \\
\mathrm{~N}=10\end{array}$} & \multicolumn{2}{|c|}{ After antibiotics } \\
\hline & & & Day 3 & Day 5 \\
\hline & & & $\mathrm{N}=8$ & $\mathrm{~N}=7$ \\
\hline $\mathrm{Su}$ & 4 & 14.800 & 19.800 & 12.100 \\
\hline $\mathrm{Au}$ & 7 & 26.900 & 14.000 & - \\
\hline $\mathrm{Re}$ & 12 & 15.000 & - & 12.600 \\
\hline $\mathrm{Sa}$ & 36 & 14.100 & 27.700 & 14.980 \\
\hline $\mathrm{Ki}$ & 5 & 14.800 & 19.800 & 12.100 \\
\hline $\mathrm{Ad}$ & 9 & 10.800 & 89.60 & 7.480 \\
\hline May & 18 & 11.500 & - & 10.500 \\
\hline Luk & 6 & 12.500 & 11.500 & - \\
\hline Mub & 6 & 13.900 & 12.900 & 6.070 \\
\hline Ber & 12 & 10.300 & 9.780 & - \\
\hline \multicolumn{2}{|c|}{$\begin{array}{l}\text { Mean } \pm \text { SD } \\
\text { (Range) }\end{array}$} & $\begin{array}{c}14.460 \pm 4.703 \\
(10.300-26.900)\end{array}$ & $\begin{array}{c}15.555 \pm 6.395 \\
(8.960-27.700)\end{array}$ & $\begin{array}{c}9.48 \pm 3.098 \\
(6.070-14.980)\end{array}$ \\
\hline
\end{tabular}

Description: (-) no data since the patient's condition worsened, invasive procedure not allowed

Table 3. Profile of CRP examination before and after antibiotic therapy

\begin{tabular}{|c|c|c|c|c|}
\hline \multirow{3}{*}{$\begin{array}{c}\text { Patients' } \\
\text { initials }\end{array}$} & \multirow{3}{*}{$\begin{array}{l}\text { Patients' } \\
\text { ages } \\
\text { (months) }\end{array}$} & \multicolumn{3}{|c|}{ WBC values $\left(10^{3} / \mathrm{mm}^{3}\right)$} \\
\hline & & \multirow{2}{*}{$\begin{array}{c}\text { Before antibiotics } \\
\text { Day } 0 \\
\mathrm{~N}=10\end{array}$} & \multicolumn{2}{|c|}{ After antibiotics } \\
\hline & & & Day 3 & Day 5 \\
\hline $\mathrm{Su}$ & 4 & 1.548 & 1.984 & 2.570 \\
\hline $\mathrm{Au}$ & 7 & 1.775 & 1.355 & - \\
\hline $\operatorname{Re}$ & 1 & 5.593 & - & 5.899 \\
\hline Sal & 36 & 1.373 & 1.748 & 3.277 \\
\hline $\mathrm{Ki}$ & 5 & 8.799 & 7.891 & 7.646 \\
\hline $\mathrm{Ad}$ & 9 & 4.457 & 5.811 & 3.863 \\
\hline May & 18 & 1.644 & - & 1.810 \\
\hline Luk & 6 & 7.532 & 6.353 & - \\
\hline Mub & 6 & 1.617 & 1.958 & 2.098 \\
\hline Ber & 12 & 1.792 & 1.853 & - \\
\hline $\begin{array}{l}\text { Mean } \pm \text { SD } \\
\text { (range) }\end{array}$ & & & $\begin{array}{c}3.61 \pm 2.80 \\
(1.373-8.799)\end{array}$ & $\begin{array}{c}3.62 \pm 2.61 \\
(1.355-7.891)\end{array}$ \\
\hline
\end{tabular}


Infection of the central nervous system results in a series of reactions in order to prevent further tissue damage and can activate the cellular repair process. A series of such process is called inflammation. The inflammatory response is one of the body's defense mechanism in response to initial infection and also an early prevention of the spread of the disease. When the microbes multiply in a host's body, there are two major defense mechanisms used in the fight against microbes, the presence of antibodies and leukocytes.

The first stage of inflammation is the occurrence of capillary dilatation, thus improving blood flow, then the microvascular structural changes that cause leukocytes and plasma proteins to migrate from capillaries and accumulate in the area of infection. Then, there is a widening of endothelial cells that will facilitate expulsion of plasma proteins from blood vessels. Neutrophils will adhere to vascular endothelium through adhesion molecules out of the microvascular and attracted to the site of infection by chemotactic agents which is followed by phagocytosis of microorganisms that cause intracellular damage. Afterwards, the leukocytes are activated and toxic metabolites and proteases are produced that can injure endothelial cells of blood and tissues. Then, three complement activation (C3) occurs, the inflammatory mediators and plasma protein are excreted (Julius et al 2003).

The cells may release cytokines IL-1 and TNF which will control leukocytes (WBC) migration into the tissue and cause inflammation, resulting in fever and leukocytosis, which is also called an increase in WBC. Increased WBC occurs in early admission to the hospital. WBC is one important component of the immune system that protects the body from a number of infections. The increase in WBC count may arise for various medical reasons. In addition, the inflammation also affects the working activity of the hepatocytes. Proinflammatory cytokines, such as IL-1 and TNF, would stimulate hepatocyte cells to increase the production of acute phase proteins, the CRP (Terry., 2013).

In central nervous system infection, there is a release of bacterial cell wall components that get into the cerebrospinal fluid (CSS). This leads to inflammation in the meninges after antibiotic therapy. Endotoxin and peptidoglycan of gram-negative organisms and fragments of gram-positive cell wall can stimulate the release of cytokines that cause prolonged inflammatory process. This process also causes an increase in CRP levels in patients with CNS infections (NAU and Helmut 2002). In the study conducted in ICU patients, CRP was used to evaluate correlation between CRP levels with infection and high mortality rate. Increasing levels of CRP may indicate the presence of an ongoing inflammatory activity and also may indicate poor prognosis of the patients (Suzana et al 2003).

Table 1 shows demographic data of the patients' age who had central nervous system infections, in which it mostly occurred those less than 1 year of age comprising $60 \%$ of the patients, while based on gender it is distributed mostly in male children. This is consistent epidemiological data showing that the incidence most commonly occurred in male children with a peak incidence at the age of 6-18 months (Novarini 2008). Data of body temperature showed that $30 \%$ of patients had body temperature range of 36-37 degrees $\mathrm{C}$ and $70 \%$ of patients with a range of temperatures above 37 degrees $\mathrm{C}$. The number of $\mathrm{WBC}$ at age $<2$ years in $30 \%$ of the patients $>17.0 \times 103 / \mathrm{mm}$ 3 and $10 \%$ of patients with WBC $>10.0 \mathrm{X} 103 / \mathrm{mm} 3$. Data on CRP patients who have scores above $10 \mathrm{mg} / \mathrm{dl}$ was found in all samples of the patients.

In this study, patients had seizure accompanied by fever. The incidence of febrile seizures is highly varied in each country, which is $2 \%-5 \%$ in the United States and Western Europe, $5 \%-10 \%$ in India, and $8.8 \%$ in Japan. Febrile seizures usually occur between the ages of 6 months to 3 years and the highest incidence is in the age of 18 months. When it occurs in children aged less than 6 months, it is caused by infection of the central nervous system (Trainor et al 2001; Rosman 2003; Pusponegoro et al 2006). In central nervous system infections caused by bacteria, the first symptoms of febrile convulsion occurs in $24 \%$ of pediatric cases (Chang et al., 2001). Fever in the patients usually caused by exogenous pyrogens which induces the release of endogenous pyrogens (IL-1, IL-6, TNF), which may increase in the hypothalamus (Rosman., 2003; Trainor et al., 2001).

\section{CONCLUSION}

In the case of central nervous system infections, CRP cannot be used as a marker antibiotics effectiveness. CRP may only be used in acute inflammatory conditions and infections.

\section{REFERENCES}

Alam, A. 2011. Kejadian meningitis bakterial pada anak usia 6-18 bulan yang menderita kejang demam pertama. Sari Pediatri 13(4): 293-298.

American College of Surgeon Committe on Trauma. 2004. Cedera kepala. Dalam: Advanced Trauma Life Support for Doctors. Ikatan Ahli Bedah Indonesia, penerjemah. Edisi 7. Komisi trauma IKABI; 168-193. 
Amsden, G.W., C.H. Ballow, J.S. Bertino, JR., and A.D.M. Kashuba, 2010, Pharmacokinetics and Pharmacodynamics of Anti-infective Agents, In:Mandell,

Archer, G.L. and R.E. Polk, 2010, Treatment And Prophylaxis of Bacterial Infections, In:Kasper, D.L and A.S. Fauci, Harrison's Infectious Diseases, USA:The MacGraw-Hill Companies, p. 354-375.

Barry B. Mook-Kanamori, Madelijn Geldhoff, Tom van der Poll and Diederik van de Beek.2011. Pathogenesis and Pathophysiology of Pneumococcal Meningitis. Clin. Microbiol, 24(3):557.

Chavez-Bueno, S and McCracken, G. H (2005). Bakterial meningitis in children. Pediatric Clinics of North America 52: 795-810.

Clyne B, Olshaker JS. 1999. The C-reactive protein. J Emerg Med;17:1019.

David Somand, MDa,WilliamMeurer, 2009. Central Nervous System InfectionsMD. Emerg Med Clin N Am. 27;89-100

Fisher RG, Boyce TG. 2005. Purulent meningitis. Dalam: Fisher RG, Boyce TG. Penyunting Moffet's pediatric infectious diseases: a problem-oriented approach. Ed 4th Philadelphia; Lippincont Williams \& Wilkins, pp. 243-264

Gessner, B. D., Sutanto, A., Linehan, M., et al. 2005. Incidences of vaccine-preventable Haemophilus influenza type B pneumonia and meningitis in Indonesian children: hamlet-randomised vaccineprobe trial. Lancet 365: 43-52.

JustineMiranda, MDa, Allan R.Tunkel, MD. 2009. Strategies and New Developments in the Management of Bacterial Meningitis. Infect Dis Clin $\mathrm{N}$ Am. 23;925-943

Kasper, Fauci et al. 2009. Harrison's Infectious Disease., Mc. Graw Hill Companies

Katherine B. Bodman-Smith, Rachel E. Gregory et al, 2004. Fc_RIIa expression with Fc_RI results in Creactive protein and IgG-mediated phagocytosis, Department of Infectious and Tropical Diseases

Kaushal.R.K, Jaswal.R.S, Goel.A, and Pathania.K. 2003. Role of C-reactive protein in deciding duration of antibiotic therapy in neonatal septicemi. Indian Pediatrics, vol. 40, no. 9, pp. 880-883.

Kumar, A. 2005. Bacterial meningitis. Department of Pediatrics and Human Development Michigan State University. College of Medicine and En Sparrow Hospital. www.emedicine.com/PED/topic198.htm.

Kwang Sik Kim.2010. Acute bacterial meningitis in infants and children. Division of Pediatric Infectious Diseases. Lancet Infect Dis ; 10: 32-42.

Lacy C.F., Armstrong, L.L., Goldman M.P., Lance L.L., 2010, Drug Information Handbook, 18th Ed., American Pharmacist Association, USA:Lexi Comp, Inc.
Lampiris, H.W. and D.S. Maddix, 2012, Clinical Use of Antimicrobial Agents, In:Katzung, B.G, S.B. Masters, and A.J.Trevor, Basic and Clinical Pharmacology 12th Ed., Mc.Graw Hill Companies, Inc, p. 901-913.

Laurence L. Brunton, John S Lazo, Keith L. Parker. 2006. Goodman \& Gilman's the Pharmacological Basis of Therapeutics. 11th Ed McGraw-Hill Companies.

Mandell Lionel A and Richard Wunderink, 2010, Principle and practice of infectious diseases., 7th. Churchill livingstone: Elsevier

M.Evoy, G.K., 2011, AHFS Drug Information, American Society of Health System Pharmacist, USA.

McDade T.W. Leonard, W.R et al.2005. Predictors of C-Reactive Protein in Tsimane. 2 to 15 Year-Olds in Lowland Bolivia. American Journal Of Physical Anthropology 128:906-913

Michael Scheld, W. Uwe Koedel, Barnett Nathan, and Hans-Walter Pfister.2002. Pathophysiology of Bacterial Meningitis: Mechanism(s) of Neuronal Injury. The Journal of Infectious Diseases ;186(Suppl 2):S225-33.

Mills.P.C and Philip. A.G. 2000. Use of C-reactive protein in minimizing antibiotic exposure: experience with infants initially admitted to a well-baby nursery. Pediatrics, vol. 106, no. 1, p. E4

Nicola Principi, Susanna Esposito. 2012. Diagnosis and therapy of tuberculous meningitis in children. Department of Maternal and Pediatric Sciences, Università degli Studi di Milano, Fondazione IRCCS Ca' Granda Ospedale Maggiore Policlinico, Via Commenda 9 Milan, Italyen

Olaf Hoffman and Joerg R. Weber.2009., Pathophysiology and treatment of bacterial meningitis. Ther Adv Neurol Disord 2(6) 401_412

Ogunlesi TA. 2013. Diagnosis and treatment of bacterial meningitis in the newborn. Niger J Paed; 40 (1): $6-14$

Pagana, K.D., and Pagana, T,J., 2002, Mosby’s Manual of Diagnostic and Laboratory Test 2nd ed., St. Louis:Mosby, Inc, pp. $77-85$.

Pedro Póvoa et al. 2002., C-reactive protein: a valuable marker of sepsis. Intensive Care Med 28:235-243

Pepys MB, Hirschfield GM. 2003., C-reactive protein: a critical update. J Clin Invest ;111:1805-12.

Philip O. Anderson, James E. Knoben,, William G. Troutman. 2002. Clinical drug data, tenth edition 2002The McGraw-Hill Companies

Prober CG. 2009. Acute Bacterial Meningitis. Nelson textbook of pediatric. Ed 18th. pp 2513-2522.

Pourcyrous.M, Henrietta S. Bada, Sheldon B. Korones, Vickie Baselski and Seok P.wong.1993. Significance of Serial C-Reactive Protein Responses in Neonatal Infection and Other disorder. Pediatrics ;92;431 
Prasad Col PL., Brig MNG Nair., Lt Col AT Kalghatgi., 2004. Childhood Bacterial Meningitis and Usefulness of C-reactive Protein. MJAFI, Vol. 61.

RazonablesR.R.2005. Meningitis. Division of Infectious Diseases Department of Medicine. Mayo Clinic College

Medicine.www.emedicine.com/med/topic2613.htm

Roland Nau, Fritz Sörgel and Hilmar W. Prange. 1998. Pharmacokinetic Optimisation of the Treatment of Bacterial Central Nervous System Infections. Clin Pharmacokinet., 35 (3): 223-246

Rosman NP. 2003. Evaluation of the child who convulses with fever. Pediatr Drugs. p: 5:457-61

Richard F. Mortensen and Wangjian Zhong. 2000. Regulation of phagocytic leukocyte activities by Creactive protein. Department of Microbiology, The Ohio State University, Columbus.

Roord J.John, Marceline Van Furth.A and Ralph Van Furth. 1996. Roles of Proinflammatory and AntiInflammatory Cytokines in Pathophysiology of Bacterial Meningitis and Effect of Adjunctive Therapy. p. 4883-4890 Vol. 64, No. 12

Saez-Llorens, X and McCracken Jr, G. H. 2003. Bakterial meningitis in children. Lancet., 361: 21392148.

S. Ehl, B. Gering, P. Bartmann, J. H*ogel, and F. Pohlandt. 1997. C-reactive protein is a useful marker for guiding duration of antibiotic therapy in suspected neonatal bacterial infection. Pediatrics, vol. 99, no. 2, pp. 216-221.
Sharon E. Mace,et al.2008. Acute Bacterial Meningitis. Emerg Med Clin N Am. 38 281-317

Stevens JP, Eames M, Kent A, Halket S, Holt D, Harvey D. 2003. Long term outcome of neonatal meningitis. Arch Dis Child Fetal Neonatal Ed;88:F179-F184.

Taskin, E., Turgut, M., Kilic, M., et al. 2004. Serum procalcitonin and cerebrospinal fluid cytokines level in children with meningitis mediators of Inflammation. 13(4): 269-273.

Teresa C. Horan, MPH, Mary Andrus, RN, BA, CIC, and Margaret A. Dudeck. 2013. CDC/NHSN surveillance definition of health care-associated infection and criteria for specific types of infections in the acute care setting. MPH Atlanta, Georgia

Terry W. Du Clos and Carolyn Mold.2003. C-Reactive Protein: Structure, Synthesis and Function. Immunobiology of Carbohydrates

Trissel, L.A, 2009, Handbook on Injectable Drugs, 15th Ed. USA:American Society of Health-System Pharmacist, Inc.

Tunkel, A. R., B. J. Hartman, et al. 2004. Practice guidelines for the management of bakterial meningitis. Clin Infect Dis 39(9): 1267-1284.

Urowayino, O. E., Afolabi, L. F., Chinyere, E. K., and Olufunmilayo, G. A. 2004. Neurological sequelae in children with pyogenic meningitis in a tertiary centre in Lagos (Nigeria). African J Neurol Sci 23: 31-38.

Ziai, W. C. and J. J. Lewin. 2008. Update in the Diagnosis and Management of Central Nervous System Infections. Neurologic Clinics 26(2): 427-468. 